\title{
POST-TSUNAMI RECONSTRUCTION IN SRI LANKA: ASSESSING THE ECONOMIC IMPACT
}

\author{
Les RUDDOCK ${ }^{1 凶}$, Dilanthi AMARATUNGA ${ }^{2}$, Nadeeshani WANIGARATNE ${ }^{3}$ \\ and Roshani PALLIYAGURU 4 \\ ${ }^{1}$ School of the Built Environment, University of Salford, Salford, Greater Manchester M5 4WT, UK \\ E-mail: L.Ruddock@salford.ac.uk \\ 2 School of the Built Environment, University of Salford, Salford, Greater Manchester M5 4WT, UK \\ ${ }^{3}$ Halcrow International Partnership, Sharjah, UAE \\ ${ }^{4}$ School of the Built Environment, University of Salford, Salford, Greater Manchester M5 4WT, UK
}

Received 17 February 2010; accepted 14 June 2010

\begin{abstract}
The "construction output shock" that was generated by the massive reconstruction programmes after the Indian Ocean tsunami in Sri Lanka spread through the economic system and was reflected in economic indicators due to the multiple linkages that the construction industry has with other economic sectors. On the ground, it was observed that the prices of construction materials, labour and plant rose suddenly in the affected regions making the reconstruction effort more costly. This paper considers the responses of major economic and construction indicators to the construction shock due to post-tsunami reconstruction and the amount of time needed before they returned to an equilibrium state. Empirical results indicate that the construction output shock had a significant impact on material, labour and equipment price indices in the short run but other indicators showed only a very marginal response indicating that the remoteness of the disaster would have delayed the propagation.
\end{abstract}

KEYWORDS: Disaster reconstruction; Construction shocks; Economic indicators; Sri Lanka

\section{INTRODUCTION}

The need to develop a resilient community capable of recovering from disasters is of increasing concern in many countries (Rotimi et al., 2009). Sri Lanka was found to be a disaster prone country in the recent past (Palliyaguru et al., 2008) and was, therefore, confronting the risk of immense loss of life and property. In addition, developing countries are identified as the countries worst-affected by hazards (Muzaffer and Omer, 2006; Amaratunga and Haigh, 2010) due to factors such as rapid population growth, poverty, ill-planned developmental activities, armed conflicts and their inability to cope with them.

A disaster is a serious disruption of the functioning of a society, causing widespread human, material, or environmental losses, which exceed the ability of the affected society to cope using only its own resources (Shaluf and Ahmadun, 2006; United Nations, 2009) and it occurs when a hazard impacts badly upon a community, which is susceptible to that hazard. It can include both natural hazards and human-induced hazards (Bosher et al., 2009) such as floods, tsunamis, tropical storms, landslides, rock falls, droughts, 
cyclones, earthquakes, communal riots, armed conflicts, fires, volcanic eruptions, epidemics and industrial disasters. Even though the area is well documented by researchers, Amaratunga and Haigh (2010) have identified the requirement for strong theories on this topic. Additionally, in identifying the role of the construction industry and built environment professions in contributing to improved resilience, they emphasised the requirement for a multi-sectoral and, perhaps, inter-disciplinary approach to disaster risk reduction.

The effect of disasters and the process of recovery should be particular researched for developing countries in the context of longterm economic development. Many studies have concluded that disasters can damage the entire economy of a country including physical and human resources, when disasters occur predominantly in developing countries (United Nations Economic and Social Commission for Asia and the Pacific, 2006; Ofori, 2002; Allotey et al., 2010). On the other hand, it has been observed that disasters can provide opportunities for sustainable development if rehabilitation efforts are integrated into long-term development strategies (Brewster, 2005). The reconstruction period after a disaster includes the long-term and often substantial investment in rebuilding the physical and social infrastructure of affected regions (Thurairajah et al., 2008). Therefore, identification of the behaviour of the construction industry and its contribution to the economy in the aftermath of a disaster provides opportunities to operate better in a similar situation. Palliyaguru et al. (2008) have identified the role of economics in disaster management, while summarising the findings of various contemporary researchers. One key role specified is that economic analysis can be used to advise decision-makers about alternative policy options. This paper considers the responses of major economic and construction indicators to construction shocks due to post-tsunami reconstruction and the amount of time needed before they return to an equilibrium state in Sri Lanka.

The construction sector is an important sector in an economy, in terms of its contribution to total output and the number of workers directly employed by the industry, particularly in the context of a developing country (Ruddock and Lopes, 2006). The construction industry has been shown to have particularly high backward linkages with other sectors in the economy (Bon and Yashiro, 1996; Bon et al., 1999; Park, 1989; Pietroforte et al., 2000; Ruddock and Ruddock, 2009) and because of these close sectoral linkages, fluctuations in construction demand have a direct influence on the demand for necessity goods and services and subsequently this affects their prices (Chan, 2002). The significant multiplier effect of the industry has been recognized for a long time and, because of this, the construction industry can be seen as an economic regulator or as a control tool of the whole economy.

Often, in an economy, construction output is highly unstable as the level of output fluctuates under the influence of demand and supply forces and the nature of the industry. With the 2004 tsunami, Sri Lanka faced one of the worst natural disasters in its history with a large proportion of losses in housing and infrastructure. After successful emergency relief operations, Sri Lanka initiated post-tsunami reconstruction of housing and infrastructure, which resulted in a massive boost in construction activities in the country. These changes (shocks), in turn caused ripple effects in the economy to be transmitted through the system because of the many linkages the industry has with other economic sectors.

Economic fluctuations are classified into impulses and propagation processes (Frish, 1993). These fluctuations are irregular in nature 
and, when they occur, a propagation process distributes their effect through the economic system. One study has shown that economic shocks (with six quarters lead), interest rate levels (with two quarters lead) and demand for goods (with three quarters lead) are the leading indicators of construction demand (Akintoye and Skitmore, 1994). Thus, it is important to identify the converse too. That is, how the economic indicators represent the effects on the economy from construction shocks.

Construction is the fourth largest sector in the Sri Lankan economy and has contributed around 6-7\% of Gross Domestic Product (GDP) over recent years. The total value of new construction lies between 45\%-60\% of total Gross Domestic Fixed Capital Formation (GDFCF) and the construction industry is responsible for 5\%-6\% of employment in the economy (CBSL, 2001-2006).

\section{THE CONSTRUCTION OUTPUT SHOCK}

On 26 December 2004, an undersea earthquake registering 9.3 on the Richter scale struck in the Indian Ocean, off the Western coast of Northern Sumatra, Indonesia. This was the most powerful earthquake experienced since the earthquake that struck Alaska in 1964, which measured 9.2 on the Richter scale. Sri Lanka was severely affected by this tsunami. In addition to the severe loss of life, coastal infrastructure and public and private property in the affected areas were severely damaged while economic activities (mainly fishing, tourism, trading and small-scale industries) were severely disrupted. Table 1 shows the reconstruction and rebuilding requirement after the tsunami. It is evident that the increase in demand for construction was huge and could truly be identified as an output shock in the industry.
Table 1. Estimates of needs assessment for reconstruction and rebuilding (US\$ million)

\begin{tabular}{|c|c|c|c|}
\hline & \multicolumn{2}{|c|}{$\mathrm{ADB} / \mathrm{JICB} / \mathrm{WB}$} & \multirow{2}{*}{$\frac{\text { GOSL }}{\text { Losses }}$} \\
\hline & Losses & Needs & \\
\hline Housing & $306-341$ & $437-487$ & 400 \\
\hline Roads & 60 & 200 & 353 \\
\hline $\begin{array}{l}\text { Water and } \\
\text { Sanitation }\end{array}$ & 42 & 117 & 205 \\
\hline Rail ways & 15 & 130 & 77 \\
\hline Education & 26 & 45 & 170 \\
\hline Health & 60 & 84 & 100 \\
\hline Agriculture & 3 & 4 & 10 \\
\hline Fishery & 97 & 118 & 200 \\
\hline Tourism & 250 & 130 & 58 \\
\hline Power & 10 & $67-77$ & 115 \\
\hline Environment & 10 & 18 & 30 \\
\hline Microfinance & - & - & 157 \\
\hline Other & 90 & 180 & 424 \\
\hline Total & $900-1000$ & $1500-1600$ & 2200 \\
\hline
\end{tabular}

Source: Asian Development Bank, Japan Bank for International Cooperation and World Bank (2005); Government of Sri Lanka (GOSL, 2005)

The preliminary assessment of damages undertaken in January 2005 through a joint effort of the Asian Development Bank (ADB), the Japan Bank for International Cooperation (JIBC) and the World Bank (WB) estimated that Sri Lanka had suffered asset damages of around US\$ 1 billion (equivalent to $4.5 \%$ of GDP), and estimated that the medium-term financing needs (including immediate relief) would be around US $\$ 1.5-1.6$ billion $(7.5 \%$ of GDP) (The Institute of Policy Studies of Sri Lanka, 2005). Economic growth in 2005 was revised downwards by about $0.5-1.0 \%$ from the original estimate of $6.0 \%$, mainly due to disruptions to the fisheries and tourism sectors. The largest financing needs were in the 
housing sector. The destruction of private assets was substantial (US $\$ 700$ million), in addition to public infrastructure and other assets based on Government of Sri Lanka data (GOSL, 2005).

The estimated reconstruction cost after the disaster rose rapidly (see Table 2 ) and one reason for this can be identified as the increase of construction cost due to increases in material, labour and equipment prices.

The funds needed for rebuilding houses and other construction activities, including public infrastructure, were initially estimated on the basis of the costs and prices that prevailed immediately after the tsunami disaster. However, there is now clear evidence that construction costs began to rise rapidly. This is of course not surprising. The scale of construction that was envisaged was several times higher than that of a normal year, with dramatic increases in demand for labour and materials. Data obtained from companies and organizations involved in house building, the Institute of Policy Studies (IPS) and field interviews indicated that total construction costs for the planned houses for tsunami-affected families had already risen by $30-50 \%$ by August 2005 (The Institute of Policy Studies of Sri Lanka, 2005). The figures for September 2006 indicated cost increases from the initial estimates to be as high as $60-80 \%$.

The volume of construction output fluctuates in response to changes in demand and supply conditions. Due to the multiple linkages that the construction industry has with other economic sectors and the entire economy, any construction output shock will spread through the economic system and be reflected in several economic indicators, such as the output of other sectors, economic growth, balance of payments, general prices etc. It is important to identify the consequences of a construction output shock to the economy for various reasons. For example, it can be used by policy makers of the country in the case of a similar situation occuring. This purpose has been identified by other researchers (Chan, 2001; Tse and Ganesan, 1997) as well. Another important point is that it can be used in identification of responsiveness of the economic indicators of the country.

Table 2. Construction cost estimation over time (thousand rupees)

\begin{tabular}{lllll}
\hline Donor & Unit area $\left(\mathrm{ft}^{2}\right)$ & $\begin{array}{l}\text { Initial estimate } \\
\text { March 2005 }\end{array}$ & $\begin{array}{l}\text { Estimate by } \\
\text { August 2005 }\end{array}$ & $\begin{array}{l}\text { Estimate by } \\
\text { September 2006 }\end{array}$ \\
\hline Red Cross & 600 & 625 & 1,000 & $1,250-1,300$ \\
CARE International & 550 & 450 & $550-650$ & $700-800$ \\
Aitken Spence Co.Ltd & 550 & 450 & $>500$ & 550 \\
World Vision Lanka & 500 & 550 & 700 & $750-800$ \\
Carita Sri Lanka & 500 & 500 & 650 & 800 \\
Sarvodaya Movement & 500 & 500 & 650 & $600-700$ \\
Forut Institute & 550 & 500 & 550 & 800 \\
\hline
\end{tabular}

Source: The Institute of Policy Studies of Sri Lanka (2006) 


\section{ECONOMIC IMPACT OF THE CONSTRUCTION OUTPUT SHOCK}

The unprecedented increase in reconstruction demand was identified as a construction output shock causing increases in the price of construction materials, labour and plant. This shock affected the whole economy and was reflected through construction industry related economic indicators.

\subsection{Research method}

This study set out to consider how quickly the economy and the construction industry returned to an equilibrium state in the aftermath of the tsunami and, to undertake such an evaluation, appropriate data were utilised from a variety of international sources (the International Monetary Fund, World Bank and United Nations) and national sources (the Sri Lanka Department of Census and Statistics, Central Bank Sri Lanka and the Institute for Construction Training and Development). In order to determine construction industry related indicators, time series data is normally used for the analysis (Chan, 2001; Chan, 2002; Tse and Ganesan, 1997; Wong et al., 2005) and, in this study, the behaviour of the national economy, post-tsunami disaster, was analysed through the employment of GDP, GDFCF, construction prices (using the Sri Lanka consumer prices index (SLCPI)), balance of payments $(\mathrm{BoP})$ and interest rate data. These indicators were selected to represent the national economy to measure impact, as previous studies have established a relationship between the national economy and the construction industry with regard to one or more of above indicators. For example, Chan (2002) established a relationship between the national economy and the construction industry using GDP and $\mathrm{BoP}$ as the indicators to represent the national economy. Construction value added (CVA), an all construction price index and GDFCF were used as other indicators of the construction industry - national economy relationship. Additionally, data on material price indices, labour price indices and equipment price indices were used to analyse the effect of the output shock on construction costs.

Quarterly data of the above indicators from 1998 Q1 to 2007 Q2 were examined and data for GDP, construction prices (using the SLCPI), BoP, interest rates, GFDFC and CVA were found using monthly and annual reports of the Central Bank, Sri Lanka. Data for the all construction cost price index, material, labour and equipment price indices were obtained from the 'Institute for Construction Training and Development' (ICTAD) construction statistics bulletins.

\subsection{Specific impact effects}

\section{Impact on construction prices}

Increases in prices for construction labour, plant and materials from the construction output shock were apparent. Figure 1 shows the effect of the output shock on construction labour prices.

It can be seen that, at the beginning of 2005 , construction labour prices in all three categories had started to rise considerably. Labour prices steadied throughout 2005 but then they showed considerable growth throughout 2006 and into 2007 and it appears that the output shock continued to cause increases in labour prices over a prolonged period. One noticeable feature is that unskilled labour prices show a higher growth rate than the other two categories.

Construction equipment prices also show a similar trend (see Figure 2). With an initial spurt at the start of 2005, they started to take off from the first quarter of year 2006 onwards. ICTAD produce two separate indices for equipment prices and the pattern for heavy equipment and small equipment was fairly similar. 


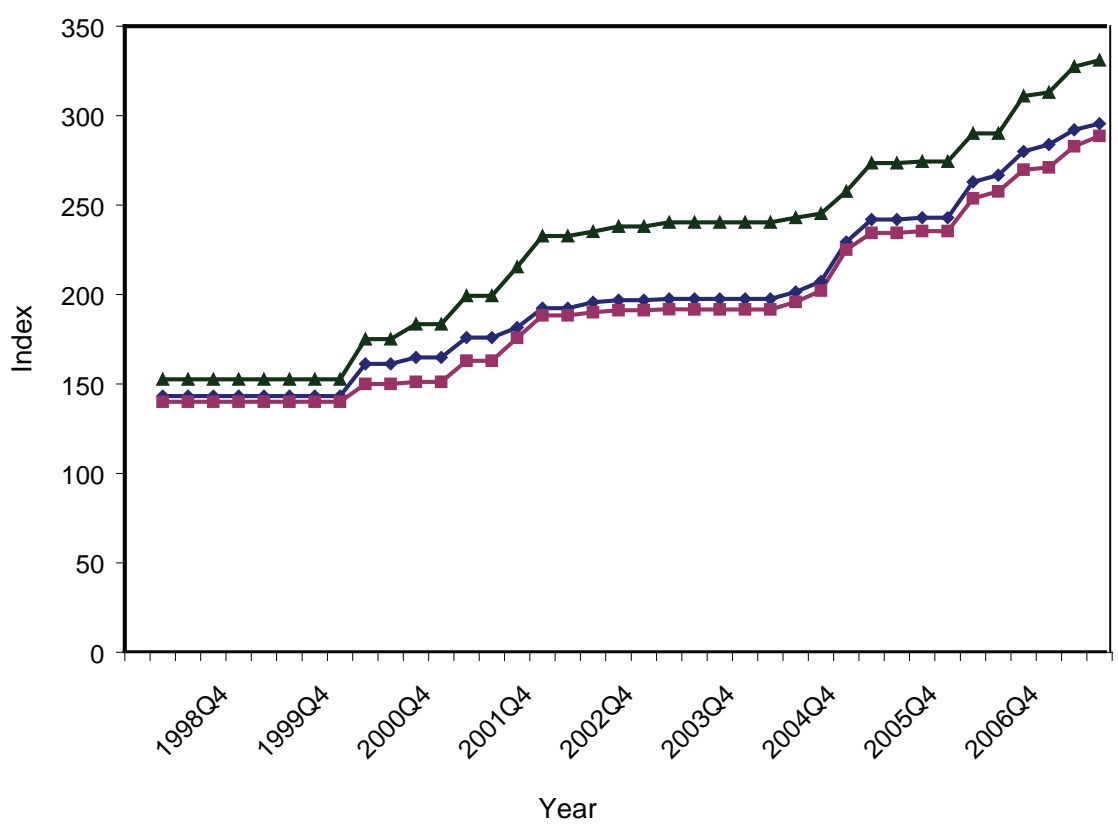

$\rightarrow$ Skilled labour

$\rightarrow-$ Semi Skilled labour

$\multimap$ Unskilled labour

Figure 1. Construction labour price indices

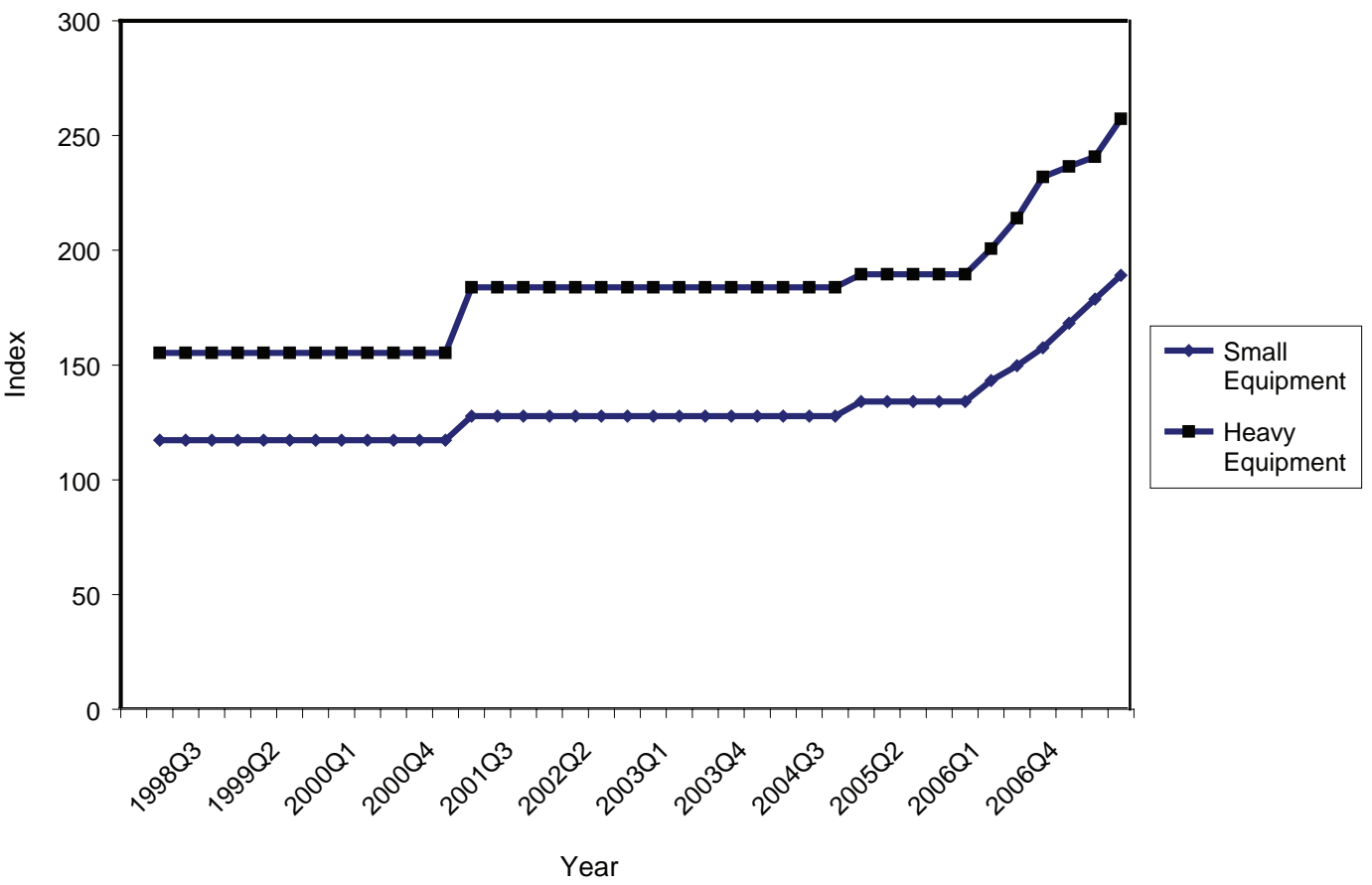

Figure 2. Construction equipment price indices 
The increased demand for equipment at the beginning of the surge in demand for construction activity caused initial price inflation as the shortage could only be reduced by extra imports of equipment.

The price behaviour of selected construction materials was analysed in order to identify the impact of output shock for construction material prices (see Figure 3).

Almost all materials prices showed a greater rate of increase at the beginning of 2005 , with bricks (hand-cut) and cement prices displaying a higher growth than other selected materials - the urgent need in the post-tsunami recovery work was for the most basic construction materials. Tiles, cement block, bricks (machine cut), timber and electrical wiring items also showed a price increase but at a lower rate. Sand prices had increased considerably in 2004 Q2 but this was due to the 'sand ban' implemented by the government at the time. From that point onwards, it continuously increased compared to the years before 2003, particularly due to the post-tsunami demand for sand. Overall, there was a noticeable increase in construction material prices due to the output shock.

\section{Impact on the construction industry}

The construction output shock affected the whole construction industry and this is reflected through various construction industryrelated indicators.

Changes in the construction cost index since 2002 are shown in Figure 4, which depicts a similar pattern to those of the construction labour, material and equipment prices indices as described previously. That is, costs had increased from 2005 Q2 and show a high growth rate in 2006, with a specific spike in Q1.

CVA had increased in 2005 but then decreased in 2006 Q2 and GDFCF showed a similar trend in that it increased most rapidly in 2005 Q3. This is mainly explained by the fact that, in 2006, the initial spurt in construction activity in 2005 was beginning to be replaced by a need for greater services provision. There was a higher GDP contribution from the services sector due to the improved performance of that sector during the year (CBSL, 2006). The behaviour of the construction cost index differs from the other two indicators in that, in $2006 \mathrm{Q} 2$, the construction cost index still showed growth, while the other two showed a decrease in value.

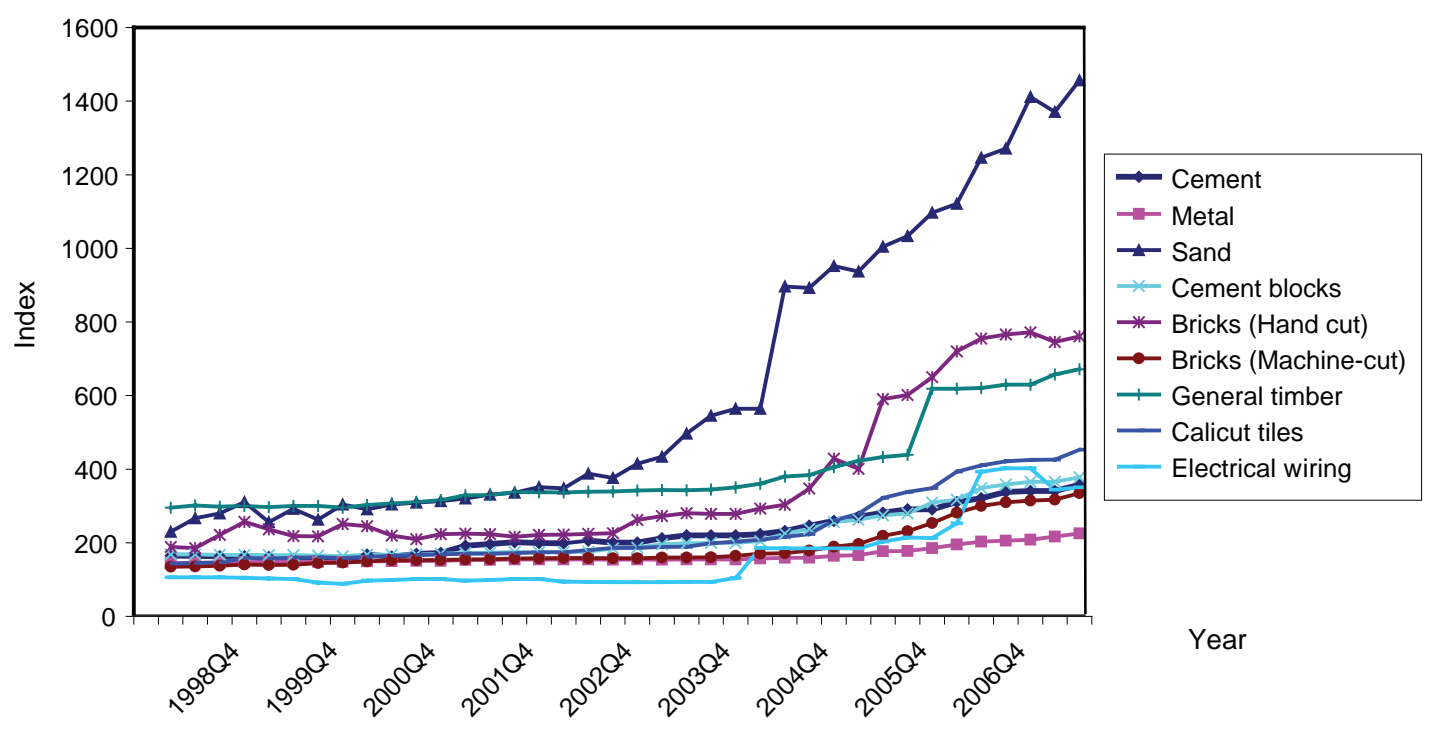

Figure 3. Selected construction material price indices 


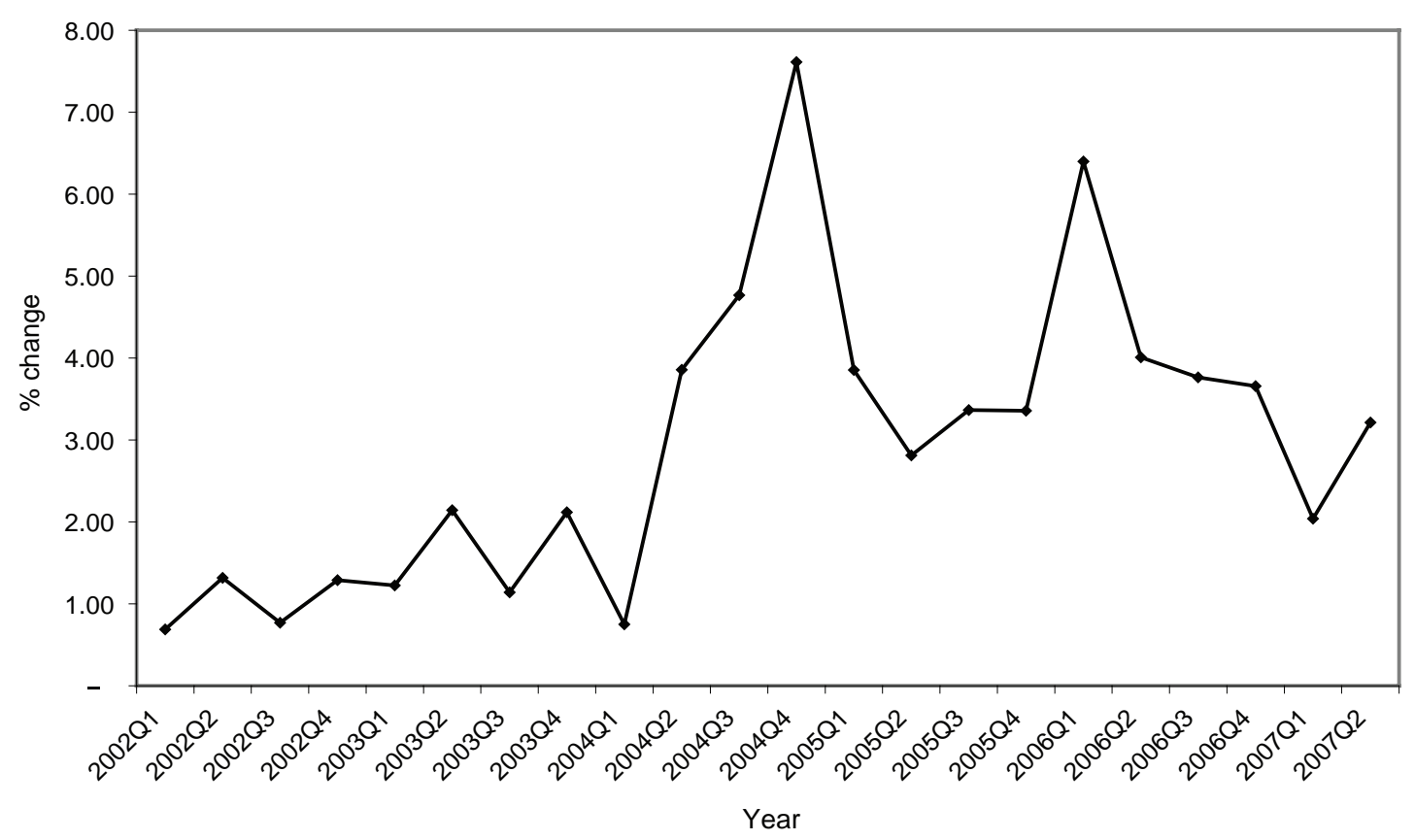

Figure 4. Change in the all construction cost index (Quarterly \%)

\subsection{Impact on the national economy}

Economic status of Sri Lanka pre-tsunami

In order to assess the consequences of the output shock to the economy in general, the state of the economy at the end of 2004 must firstly be considered.

The Sri Lankan macroeconomy had already been under pressure since 2001 for several reasons. In 2001, GDP fell by 4\% for the year as a whole, recording an annual negative economic growth in Sri Lanka for the first time since it regained independence in 1948 (CBSL, 2001), due to a deteriorating domestic policy and political environment, lower exports resulting from depressed global economic conditions and lower agricultural output caused by adverse weather conditions (The Institute of Policy Studies of Sri Lanka, 2006). The rate of inflation rose to $14.2 \%$ from $6.2 \%$ and the high interest rate levels also reflected an economic crisis situation in 2001 (CBSL, 2001).
The economy showed gradual signs of recovery until 2004, due to the prospect of a lasting peace and a substantive set of economic reforms including the floating of the currency, which succeeded to some extent in garnering donor support and renewing investor confidence (The Institute of Policy Studies of Sri Lanka, 2006). GDP rose by $4.0 \%$ and $6.0 \%$ respectively in 2002 and 2003 (CBSL, 2002; CBSL, 2003). The current account deficit on the $\mathrm{BoP}$ was in the range $-0.4 \%$ to $-1.4 \%$ of GDP throughout 2001-2003. Similarly, the trade account deficit on the $\mathrm{BoP}$ also showed a narrowing trend over the period (CBSL, 2001; CBSL, 2002; CBSL, 2003).

At the end of 2004, Sri Lanka's economy again showed symptoms of an ecomic slowdown due to election-related uncertainities and policy weaknesses (The Institute of Policy Studies of Sri Lanka, 2006). GDP growth of $5.4 \%$ showed a declining trend compared to 
previous years (CBSL, 2001). The growth rate was below the $6-8 \%$ rate required for a sustainable reduction in unemployment and poverty in Sri Lanka. Inflation, which was mostly benign throughout 2003, rose in 2004 to $7.9 \%$ with the drought and the higher fuel prices leading to high cost-push inflation, while the increase in money supply and fiscal expansion, caused demand-pull inflation (CBSL, 2004). Both trade and current accounts in the BoP recorded deficits. A high import growth rate of $20 \%$, largely due to high international fuel prices, surpassed the $12 \%$ growth in exports and the $11 \%$ increase in worker remittances. Consequently, the effective exchange rate depreciated by $11 \%$ (1.1\% in real terms) (CBSL, 2004). Towards the end of 2004 , policy makers were faced with several risk concerns. First, the risk of further escalation of international oil prices exerted a heavy burden on the economy and the people. Second, the global economy had already shown signs of slowing down, which threatened Sri Lanka's export performance. Third, Sri Lanka's major export industry, textiles and garments, was faced with increased competition in the world market due to the imminent phasing out of the Multi Fibre Arrangement.

While the country was preparing itself to face the challenges of growing macroeconomic imbalances, the year ended with the unexpected and unprecedented devastation caused by the tsunami.

\subsection{Post-tsunami national economic performance}

\section{Impact on economic growth}

Growth in GDP had started to slow down at the end of 2004 and it became negative at $-2.0 \%$ and $-5.5 \%$ in $2005 \mathrm{Q} 1$ and Q2 respectively but then grew again at $12.1 \%$ in 2005 Q3. Sri Lanka's economy demonstrated its resilience in 2005 by growing at an overall rate of $6 \%$, exceeding the expectations in the imme- diate aftermath of the 2004 tsunami disaster. The year started with several challenges posed by domestic and external shocks and their related uncertainties. The impact of the tsunami necessitated a massive volume of resources for a quick recovery. Additionally, oil prices were escalating rapidly, the Multi-Fibre Arrangement (MFA) came to an end on $1^{\text {st }}$ January 2005, election-related uncertainty loomed large and the peace process was at a standstill. As the year progressed, the uncertainties began to dissipate and there was a renewed vigour in the economy, providing sufficient room for policy manoeuvrability to maintain both price and financial stability. There was a relatively small impact on GDP with regards to the extent of the asset and human losses, which was partly because only a comparatively small sector of the economy was affected. Further, the impact on current GDP measures only the loss of services from destroyed capital assets and human resources during that current year. The overall impact of the tsunami on national income is of course much larger, being the cumulative sum of such annual losses incurred in future due to the absence of the destroyed assets (CBSL, 2005).

Figure 5 shows that the level of GDFCF accelerated in the post-tsunami period as a consequence of the reconstruction investment and made a major contribution to the growth in GDP of $7.4 \%$ in real terms in 2006, recording the highest growth since 1978. This economic growth was accompanied by an increase in the price level, particularly in the second half of the year. This growth was commendable as it was achieved in a challenging environment marked by high and volatile oil prices and renewed terrorism activities. The industry sector grew by $7.2 \%$ ( $8.3 \%$ in 2005$)$. The deceleration in this sector was mainly due to lower growth in all the sub-sectors including construction affected by increased costs of imports, raw materials and wages (CBSL, 2006). 


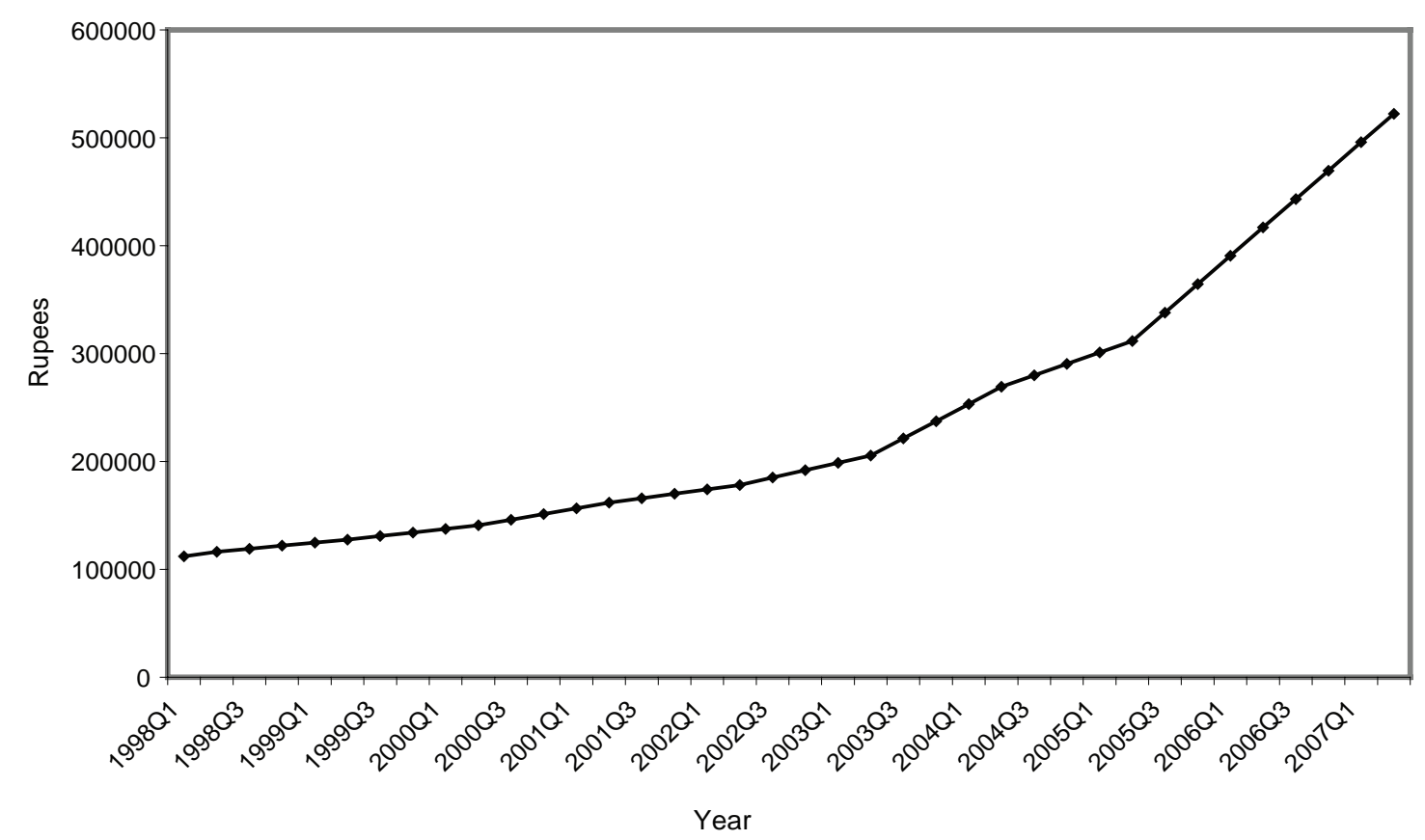

Figure 5. Gross domestic fixed capital formation

\section{Impact on inflation}

The annual average inflation rate in 2005 was $11.6 \%$. Domestic as well as external demand and supply factors impacted on the observed price changes at both wholesale and retail market levels. The impact of the tsunami and the consequent price rises in the construction sector also affected prices adversely. However, expansion in agricultural production, particularly of paddy, reduced the pressure on prices after the first quarter of the year. The pressure on prices from the demand side was reflected in the relatively high expansion of monetary and credit aggregates, particularly consumption credit, throughout the year, while tightening the monetary policy stance helped to contain inflationary expectations during 2005 (CBSL, 2005).

2006 commenced with a moderation of consumer price inflation, in response to tight monetary policy aided by growth in domestic production. However, the developments that took place thereafter, particularly, the escalation of oil prices, led to a reversal of this trend exerting pressure on inflation during the remainder of the year. The rising inflation rate was reflected in the annual average increase recorded by all price indices.

\section{Impact on the balance of payments}

There is a strong relationship between construction industry performance and the national economic performance in terms of the BoP. The construction industry contributes around $24 \%$ annually to the trade balance in Sri Lanka (CBSL, 2006). Steel, cement, electrical items and machineries contribute $80 \%$ of total construction related imports.

Large inflows to the government and increased private remittances bolstered the ex- 
ternal financial position, leading to a surplus in the balance of payments and an appreciation of the rupee in 2005. Net inflows to the government increased by over $50 \%$ in 2005 with large tsunami- related inflows, and lower debt service payments resulting from the debt moratoria following the tsunami, contributing to an overall BoP surplus of US\$ 501 million (CBSL, 2005). The highest ever growth in worker remittances and highest ever inflows of foreign direct investment and external financing to the government helped to finance growing trade and current account deficits, resulting in a surplus of US $\$ 204$ million in the country's balance of payments in 2006 (CBSL, 2006).

\section{Impact on interest rates}

The Bank Rate remained unchanged. The Bank Rate, the rate at which the Central Bank grants advances to commercial banks to meet urgent liquidity requirements against collateral such as government securities, gold and commercial bills, remained at $15 \%$ in 2005 . The monetary policy of the Central Bank in 2006 was focused on reducing high inflation and inflationary expectations while supporting a sustainable high economic growth in 2006 . An upward trend in the interest rate reflected higher inflation expectations, which had been exacerbated by the high prices of construction labour and imported construction materials.

\section{CONCLUSIONS}

The massive reconstruction work after the tsunami disaster in Sri Lanka caused an output shock in the construction industry. Since the construction industry plays a major role in the economy it was argued that the economic impact of the output shock could be reflected through the economic indicators in the country. This study found an increase in material, labour and equipment prices due to the output shock, with considerable increases in the case of hand-cut bricks, cement and unskilled labour prices. This inflation in construction costs started in 2005 and continued until 2007 with increases in prices but at declining rates.

The impact of the output shock was also reflected through the construction industry related indicators - the all construction cost index, CVA and GDFCF. The all construction cost index showed a similar trend to those of construction material, labour and plant prices and CVA and CGDFCF increased considerably in 2005 but then started to decline in 2006 . The increase in 2005 was identified as an impact of output shock and the decrease in year 2006 was due to a shift of emphasis by the government to the delivery of essential utility services, once that the initial building infrastructure was in place.

The government had implemented policies to increase the performance of the economy and the impact of the output shock was mitigated by those circumstances. As Figure 6 illustrates, post-tsunami construction activity growth remained at a higher level until 2007.

Only the inflation rate (measured by SLCPI) showed considerable growth over a longer period after the output shock, and one reason for that was identified as the price increases caused by shortages in the post-disaster period. Post-tsunami reconstruction provided initially a considerable boost to construction activity in the country. This caused ripple effects in the linked areas of the economy (particularly in the utility services) and gave rise to higher growth rates in GDP. However, it can be concluded that the construction output shock was reflected through the construction prices and construction industry related indicators but had only a short lasting effect on the overall economy at a greater level. 


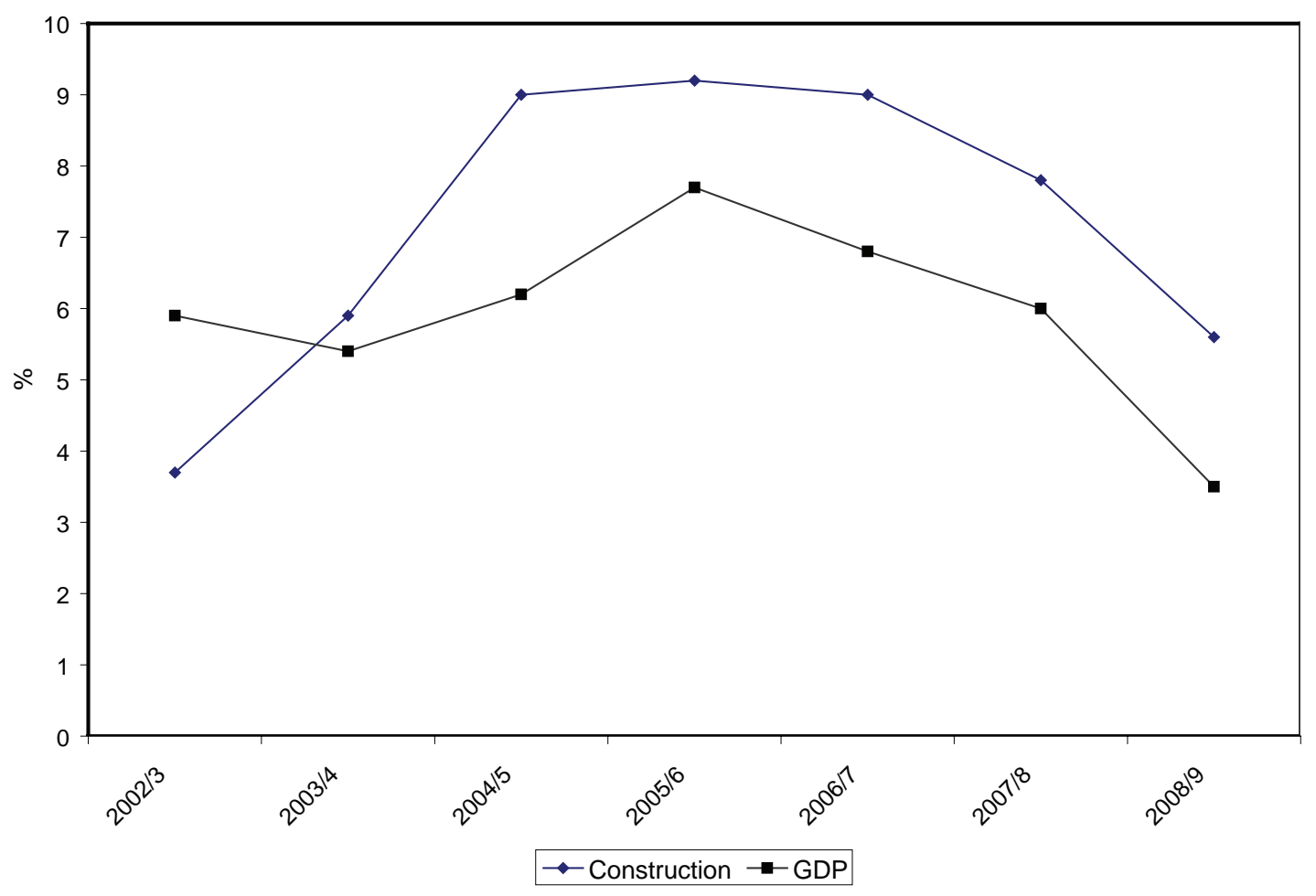

Figure 6. Growth rate of GDP and Construction at Constant (2002) prices Source: Department of Census and Statistics, Sri Lanka (2010)

\section{REFERENCES}

Akintoye, A. and Skitmore, M. (1994) Models of UK private sector quarterly construction demand, Construction Management and Economics, 12(1), pp. 3-13. doi:10.1080/01446199400000002

Allotey, N. K., Arku, G. and Amponsah, P. E. (2010) Earthquake-disaster preparedness: the case of Accra, International Journal of Disaster Resilience in the Built Environment, 1(2), pp. 140156. doi:10.1108/17595901011056613

Amaratunga, D. and Haigh, R. (2010) Disaster and the built environment: towards a mature discipline, Editorial of International Journal of Disaster Resilience in the Built Environment, International Journal of Disaster Resilience in the Built Environment, 1(1), pp. 11-24.

Asian Development Bank, Japan Bank for International Cooperation and World Bank (2005) Sri Lanka 2005 Post-Tsunami Recovery Program: Preliminary Damage and Needs Assessment, January 2005.
Bon, R. and Yashiro, T. (1996) Some new evidence of old trends: Japanese construction 1960-1990, Construction Management and Economics, 14(4), pp. 319-323. doi:10.1080/014461996373395

Bon, R., Birgonul, T. and Ozdogan, I. (1999) An input-output analysis of the Turkish construction sector, 1973-1990: A note, Construction Management and Economics, 17(5), pp. 543-551. doi:10.1080/014461999371169

Bosher, L., Dainty, A., Carrillo, P., Glass, J. and Price, A. (2009) Attaining improved resilience to floods: a proactive multi-stakeholder approach, Disaster Prevention and Management, 18(1), pp. 9-22. doi:10.1108/09653560910938501

Brewster, R. (2005) Natural disaster recovery planning, In: Proceedings of the Conference on Built Environment Issues in Small Island States, University of Technology, Kingston, Jamaica, 2-6 August 2005. 
CBSL (2000; 2001; 2002; 2003; 2004; 2005; 2006) Central Bank Annual Reports, Central Bank of Sri Lanka (CBSL), Colombo, Sri Lanka.

Chan, S. L. (2001) Empirical tests to discern linkages between construction and other economic sectors in Singapore, Construction Management and Economics, 19(4), pp. 355-363. doi:10.1080/01446190010022686

Chan, S. L. (2002) Response of selected economic indicators to the construction output shock: the case of Singapore, Construction Management and Economics, 20(6), pp. 523-533. doi:10.1080/01446190210156091

Frish, R. (1993) Propagation problems and impulse problems in dynamic economics, In: Economic Essays in Honor of Gustau Cassel, 1993. Reprinted in Gordon, R. A. and Klien, L. R. (1965) Readings in Business Cycles, Irwin, Homewood, II, pp. 155-185.

GOSL (2005) Interim Report of the Auditor General on the Rehabilitation of the Losses and Damages Caused to Sri Lanka by the Tsunami, Government of Sri Lanka (GOSL), September 2005.

Muzaffer, B. and Omer, F. (2006) Post-disaster reconstruction in rural and urban areas of Turkey, In: Proceedings of the International Conference and student competition on post-disaster reconstruction: Meeting Stakeholder Interests, 17-19 May 2006, Florence, Italy. Available at: www. grif.umontreal.ca/pages/papersmenu2006.htm [accessed 2 February 2010]

Ofori, G. (2002) Construction Industry Development for Disaster Prevention and Response, In: Proceedings of the $i$-Rec Conference on Improving Post-Disaster Reconstruction in Developing Countries, University de Montreal, Canada, May 2002. Available at: www.GRIF.UMontreal.ca/pages/papersmenu.html [accessed 2 February 2010]

Palliyaguru, R., Amaratunga, D. and Haigh, R. (2008) Economic development perspectives of post-disaster infrastructure reconstruction in Sri Lanka, In: Proceedings of the International Conference in Building Education and Research, February 2008, Sri Lanka.

Park, S. H. (1989) Linkages between industry and services and their implications for urban employment generation in developing countries, Journal of Development Economics, 30(2), pp. 359-379.

doi:10.1016/0304-3878(89)90009-6
Pietroforte, R., Bon, R. and Gregori, T. (2000) Regional development and construction in Italy: an input-output analysis, 1959-1992, in Bon, B. (ed.), Economic structure and maturity: Collected papers in input-output modelling and applications, Ashgate, Aldershot.

Rotimi, J. O., Wilkinson, S., Zuo, K., and Myburgh, D. (2009) Legislation for effective post disaster reconstruction, International Journal of Strategic Property Management, 13(2), pp.143-152. doi:10.3846/1648-715X.2009.13.143-152

Ruddock, L. and Lopes, J. (2006) The construction sector and economic development: the 'Bon curve', Construction Management and Economics, 24(7), pp. 717-723. doi:10.1080/01446190500435218

Ruddock, L. and Ruddock, S. (2009) The Scope of the Construction Sector: Determining its Value. In: Ruddock, L. (ed.), Economics for the Modern Built Environment, Taylor and Francis, London, pp. 79-93.

Shaluf, I. M. and Ahmadun, F. (2006) Disaster types in Malaysia: an overview, Disaster Prevention and Management, 15(2), pp. 286-298. doi:10.1108/09653560610659838

The Institute of Policy Studies of Sri Lanka (2006) Post-Tsunami Recovery: Issues and Challenges in Sri Lanka. Colombo, The Institute of Policy Studies of Sri Lanka.

The Institute of Policy Studies of Sri Lanka (2005) Economic Challenges of Post-Tsunami Reconstruction: Sri Lanka Two Years On. Colombo, The Institute of Policy Studies of Sri Lanka.

Thurairajah, N., Amaratunga, D. and Haigh, R. (2008) Post-disaster reconstruction as an opportunity for development: women's perspective, In: Proceedings of the International Conference in Building Education and Research, February 2008, Sri Lanka.

Tse, R. Y. C. and Ganesan, S. (1997) Causal relationship between construction flow and GDP: evidence from Hong Kong, Construction Management and Economics, 15(4), pp. 371-376. doi:10.1080/014461997372926

Wong, J. M. W., Chan, A. P. C. and Chaing, Y. H. (2005) Time series forecasts of the construction labour market in Hong Kong: the Box-Jenkins approach, Construction Management and Economics, 23(9), pp. 979-991. doi:10.1080/01446190500204911 
United Nations (2009) International Strategy for Disaster Reduction (UN/ISDR), http://www. unisdr.org/eng/library/lib-terminology-eng-p. htm UN/ISDR Terminology on disaster risk reduction (2009). Available at: http://www. unisdr.org/eng/library/lib-terminology-eng.htm [accessed 2 February 2010]
United Nations Economic and Social Commission for Asia and the Pacific (2006) Enhancing regional cooperation in infrastructure development including that related to disaster management, United Nations, Bangkok.

\section{SANTRAUKA}

\section{ATSTATOMIEJI DARBAI ŠRI LANKOJE PO CUNAMIO: POVEIKIO EKONOMIKAI IVERTINIMAS}

\section{Les RUDDOCK, Dilanthi AMARATUNGA, Nadeeshani WANIGARATNE, Roshani PALLIYAGURU}

Dèl didžiuliu atstatymo programu, prasidejusių Šri Lankoje po cunamio Indijos vandenyne, atsiradęs statybu šokas apėmė ekonominę sistemą ir padarè poveikį ekonominiams rodikliams, nes statybos pramonè turi daugybę sasajų su kitais ūkio sektoriais. Pastebèta, kad nukentėjusiuose regionuose statybiniu medžiagu, darbo ir irangos kainos staiga išaugo, o atstatomoji veikla pabrango. Šiame straipsnyje nagrinejama, kaip pagrindiniai ekonominiai ir statybos rodikliai reaguoja i statybu šoka, patirtą dèl atstatomuju darbu po cunamio, kiek laiko reikia, kad rodikliai grižtų i pusiausvyros būklę. Iš empirinių rezultatu matyti, kad trumpuoju laikotarpiu statybų apimties šokas gerokai paveikè medžiagų, darbo ir ịrangos kainų rodiklius, bet kiti rodikliai kito labai nedaug, vadinasi, nelaimès atokumo atveju rodiklių sklaida būtų buvusi sulaikyta. 